(c) American Dairy Science Association, 2007.

\title{
Ovarian Traits After Gonadotropin-Releasing Hormone-Induced Ovulation and Subsequent Delay of Induced Luteolysis in an Ovsynch Protocol ${ }^{1}$
}

\author{
J. S. Stevenson, ${ }^{2}$ M. A. Portaluppi, and D. E. Tenhouse \\ Department of Animal Sciences and Industry, Kansas State University, Manhattan 66506-0201
}

\begin{abstract}
Our objective was to determine whether delaying the $\mathrm{PGF}_{2 \alpha}$ injection by 24 or $48 \mathrm{~h}$ after the first $\mathrm{GnRH}$ injection in an Ovsynch protocol (from a standard $7 \mathrm{~d}$ ) altered ovarian characteristics in lactating dairy cows. Beginning $9 \mathrm{~d}$ after removal of a progesterone-releasing controlled internal drug release (CIDR) insert and injection of $\mathrm{PGF}_{2 \alpha}$ (d 6.4 of the estrous cycle), 36 Holsteins (average body weight $=707 \pm 12 \mathrm{~kg}$ and body condition score $=$ $2.3 \pm 0.1)$ were administered $100 \mu \mathrm{g}$ of $\mathrm{GnRH}(81 \pm 2 \mathrm{~d}$ in milk) and assigned randomly to receive a treatment injection of $\mathrm{PGF}_{2 \alpha} 7,8$, or $9 \mathrm{~d}$ later. Timed artificial insemination was performed at $48 \mathrm{~h}$ after $\mathrm{PGF}_{2 \alpha}$ at which time a second injection of GnRH was administered. Ovarian structures were mapped by ultrasonography on d 0 (first $\mathrm{GnRH}$ injection); on d 2 to determine responses to the first $\mathrm{GnRH}$ injection; at $\mathrm{PGF}_{2 \alpha}$ injection; and daily thereafter through $72 \mathrm{~h}$ after $\mathrm{PGF}_{2 \alpha}$ to monitor ovulation of preovulatory follicles. Blood was collected on d 0,2 , at $\mathrm{PGF}_{2 \alpha}$ injection, and at 24 and $48 \mathrm{~h}$ after $\mathrm{PGF}_{2 \alpha}$ to monitor serum changes in estradiol-17 $\beta$ (E2$17 \beta)$ and progesterone (P4). Based on serum P4 and ovarian exams, 2 cows were eliminated because of anestrus and their failure to ovulate a follicle in response to the first GnRH injection. Two other cows in which luteolysis failed to occur after $\mathrm{PGF}_{2 \alpha}$ treatment also were eliminated. Final numbers of cows per treatment were: $7 d(n=13), 8 d(n=9)$, and $9 d(n=10)$. Twenty-nine of 32 cows ovulated $(90.6 \%)$ in response to the first $\mathrm{GnRH}$ injection. Of those cows not ovulating in response to the first GnRH injection, 2 had 1 original corpus luteum and 1 had 2 original corpora lutea. Despite a 24 - or 48 -h delay between first $\mathrm{GnRH}$ and $\mathrm{PGF}_{2 \alpha}$ injections, the diameter $(\mathrm{mm})$ and volume $\left(\mathrm{mm}^{3}\right)$ of the ovulatory follicle did not differ among treatments: $14.3 \pm 0.6$ and 1,526 \pm 62 at 7 d; $14.1 \pm 0.8$ and $1,479 \pm 97$ at $8 \mathrm{~d}$; and $15.3 \pm 0.9$ and
\end{abstract}

Received July 26, 2006

Accepted October 11, 2006.

${ }^{1}$ Contribution no. 07-004-J, Kansas Agricultural Experiment Station, Manhattan.

${ }^{2}$ Corresponding author: jss@k-state.edu
$1,490 \pm 69$ at $9 \mathrm{~d}$. In all 32 cows, at least 1 follicle ovulated after treatment, but ovulation rates did not differ: $1.2 \pm$ $0.1,1.1 \pm 0.1$, and $1.3 \pm 0.2$, respectively, for the 7-, 8-, and 9-d treatments. Serum concentrations of E2-17 $\beta$ did not differ among treatments. Four cows in the 7-d treatment were inseminated $24 \mathrm{~h}$ late and were excluded before assessing conception rates, which were 5/9 (55.6\%), 5/9 (55.6\%), and 1/10 (10\%), respectively. We conclude that delaying $\mathrm{PGF}_{2 \alpha}$ injection by $24 \mathrm{~h}$ had no effect on outcomes.

Key words: Ovsynch, ovulation, follicle, timing of luteolysis

\section{INTRODUCTION}

Before the advent of the Ovsynch protocol (injection of $\mathrm{GnRH} 7 \mathrm{~d}$ before and $48 \mathrm{~h}$ after an injection of $\mathrm{PGF}_{2 \alpha}$, with 1 timed $\mathrm{AI}$ at 12 to $16 \mathrm{~h}$ after the second $\mathrm{GnRH}$ injection; Pursley et al., 1997), 33\% of all dairy operations were using some type of systematic $\mathrm{PGF}_{2 \alpha}$ program to synchronize estrus (National Animal Health Monitoring System, 1996), with rates of use greater for operations with 200 or more cows $(50.2 \%)$ than for those with 100 to 199 cows $(45 \%)$ or less than 100 cows $(31.1 \%)$. Since then, timed AI (TAI) protocols likely have become even more popular among dairy producers and are used in nearly $10 \%$ of all US dairy herds (Lucy, 2001).

Development of synchronized ovulation was based on earlier reports in which a new follicular wave was initiated in response to an injection of GnRH 6 to $7 \mathrm{~d}$ before $\mathrm{PGF}_{2 \alpha}$-induced luteolysis (Thatcher et al., 1989; Twagiramungu et al., 1995; Pursley et al., 1997). Emergence of a new follicular wave in response to $\mathrm{GnRH}$ led to greater homogeneity of ovarian follicular inventories among cows at the time of induced luteolysis (Twagiramungu et al., 1995). Improved synchrony of estrus resulting from coordinated follicular maturation and luteal regression (after administering $\mathrm{GnRH} 7 \mathrm{~d}$ before $\mathrm{PGF}_{2 \alpha}$ ) was first demonstrated in dairy heifers (Thatcher et al., 1989), and later in lactating dairy (Stevenson et al., 1999) and beef cattle (Twagiramungu et al., 1992a,b). In consequence, $\mathrm{GnRH}$ treatment of cows 6 to $7 \mathrm{~d}$ before induced luteolysis resulted in 70 to $83 \%$ of heifers or 
cows in estrus during a 4-d period (Thatcher et al., 1989; Twagiramungu et al., 1992a,b). Furthermore, using a GnRH agonist $6 \mathrm{~d}$ before $\mathrm{PGF}_{2 \alpha}$-induced luteal regression improved precision of estrus that occurred without any detrimental effect on fertility of beef cows (Twagiramungu et al., 1995).

Administration of $\mathrm{GnRH}$ reduces occurrence of estrus during 6 to $7 \mathrm{~d}$ after $\mathrm{GnRH}$ injection (Thatcher et al., 1989; Twagiramungu et al., 1992a,b). Reduced estrus during the post-GnRH period occurs because of ovulation of the dominant follicle and formation of a new or ancillary corpus luteum $(\mathbf{C L})$ during the luteal phase (Twagiramungu et al., 1994a,b; Pursley et al., 1995), resulting in decreased peripheral concentrations of serum estra$\operatorname{diol-17} \beta$ (E2-17 $\beta$; Twagiramungu et al., 1994b). In lactating dairy cows, the average incidence of ovulation is about $64 \%$ when cows are injected across various stages of the estrous cycle (Vasconcelos et al., 1999).

Once a new dominant follicle is selected, concentrations of $\mathrm{E} 2-17 \beta$ increase, $\mathrm{LH}$ pulses increase, and the selected dominant follicle becomes the preovulatory follicle. Maximum concentrations of E2-17 $\beta$ in serum preceding ovulation, however, are 30\% less in lactating dairy cows than in nulliparous heifers, even though ovulatory follicles are 13\% greater in diameter (Sartori et al., 2004). Further, maximum concentrations of progesterone (P4) are $30 \%$ less in cows than in heifers, despite cows having $53 \%$ more luteal tissue (Sartori et al., 2004). Discrepancies between sizes of ovarian structures and serum steroid concentrations may result from greater rates of steroid metabolism in lactating dairy cows than in heifers (Sangsritavong et al., 2002) and in cows of various milk-producing abilities (Lopez et al., 2004).

Reduced serum steroid concentrations may have numerous potential physiologic consequences that compromise fertility in lactating cows. We hypothesized that greater concentrations of serum E2-17 $\beta$ in lactating cows may occur when using the Ovsynch protocol if $\mathrm{PGF}_{2 \alpha^{-}}$ induced luteolysis is delayed after the first $\mathrm{GnRH}$ injection. Our objective was to determine whether lengthening the interval between the first $\mathrm{GnRH}$ injection and $\mathrm{PGF}_{2 \alpha}$ from $7 \mathrm{~d}$ to 8 or $9 \mathrm{~d}$ might result in greater serum concentrations of E2-17 $\beta$ and larger follicles, possibly leading to increased fertility after a TAI.

\section{MATERIALS AND METHODS}

\section{Herd Management}

The experiment was conducted at the Kansas State University Dairy Teaching and Research Center, with 36 lactating Holstein cows that calved between August and September 2004 and had an average BCS of $2.3 \pm$ 0.1 . Daily test-day milk yield of these cows nearest to the day of first AI averaged $49.6 \pm 1.7 \mathrm{~kg}$ (3.5\% fat and

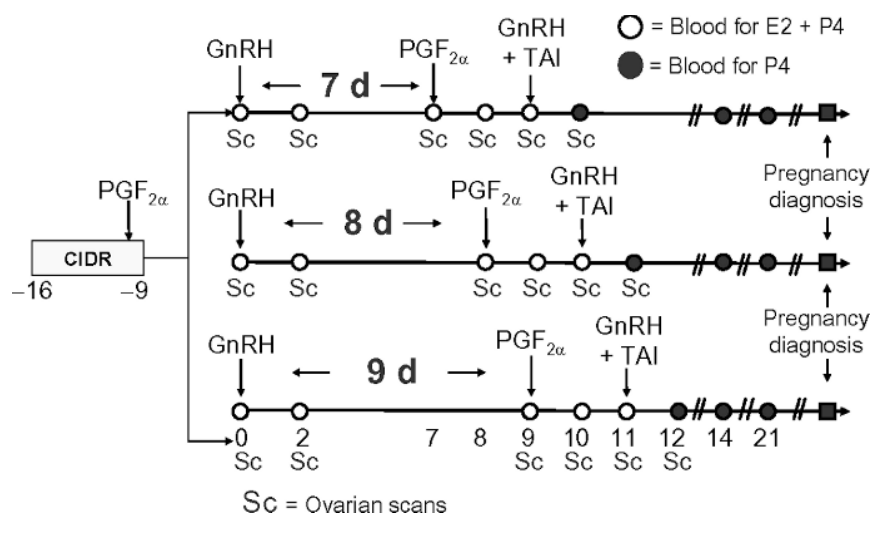

Figure 1. Experimental design for presynchronizing estrous cycles in lactating dairy cows before applying treatments. All cows received a controlled internal drug release (CIDR) insert for $7 \mathrm{~d}$, with an injection of $\mathrm{PGF}_{2 \alpha}$ given $24 \mathrm{~h}$ before removal of the CIDR insert. Nine days after CIDR insert removal, cows were allocated randomly to 1 of 3 treatments: $\mathrm{PGF}_{2 \alpha}$ at 7, 8, or $9 \mathrm{~d}$ after the first $\mathrm{GnRH}$ injection (d 0). Inseminations were administered at $48 \mathrm{~h}$ after $\mathrm{PGF}_{2 \alpha}$, at which time the second GnRH injection was administered. Pregnancy was diagnosed 32 to $34 \mathrm{~d}$ after the timed AI (TAI).

$3.0 \%$ protein) and 305-d mature-equivalent yield averaged 15,356 $\pm 429 \mathrm{~kg}$. Cows were housed in covered freestalls bedded with sand, and were fed thrice daily a TMR that met or exceeded NRC (2001) requirements for lactating cows. The TMR consisted of 30\% chopped alfalfa hay, $19 \%$ wet corn gluten meal, $15 \%$ corn silage, $9.3 \%$ whole cottonseed, $4.4 \%$ solvent-extracted soybean meal, $3.3 \%$ expeller soybean meal, $13 \%$ corn grain, $1.3 \%$ menhaden fish meal, $1 \%$ sugar cane wet molasses, and $3.7 \%$ mineral-vitamin premix. Cows had ad libitum access to fresh water. Pens were covered with shade cloth, and water was applied by sprinklers 6 times per hour for 1 min during May to October.

\section{Experimental Design}

Beginning at $65 \pm 2$ DIM, estrous cycles were synchronized in lactating dairy cows (BW $=707 \pm 12 \mathrm{~kg}$ ) by applying a P4-releasing, intravaginally placed, controlled internal drug release (CIDR) insert (Eazi-Breed CIDR, Pfizer Animal Health, New York, NY) for $7 \mathrm{~d}$, plus $25 \mathrm{mg}$ of $\mathrm{PGF}_{2 \alpha}$ (Lutalyse, Pfizer Animal Health, New York, NY) given $24 \mathrm{~h}$ before removal of the CIDR insert (Figure 1). Nine days after removal of the CIDR insert (approximately d 6 of the estrous cycle), cows received $100 \mu \mathrm{g}$ of GnRH (Cystorelin, Merial Ltd., Iselin, $\mathrm{NJ}$ ) and then were allocated randomly to 1 of 3 treatments in which they received $25 \mathrm{mg}$ of $\mathrm{PGF}_{2 \alpha}$ at $\mathrm{d} 7,8$, or 9 after the first GnRH injection (d 0;81 \pm 2 DIM).

Inseminations were administered at $48 \mathrm{~h}$ after $\mathrm{PGF}_{2 \alpha}$ (91 \pm 2 DIM), at which time the second $100-\mu$ g injection of $\mathrm{GnRH}$ was administered. Pregnancy was diagnosed 
32 to $34 \mathrm{~d}$ after TAI by using transrectal ultrasonography (5.0-MHz linear-array transducer, Aloka 500V; Corometrics Medical Systems, Inc., Wallingford, CT). A positive diagnosis included confirmation of a CL, uterine fluid, and an embryonic heart beat.

Ultrasonography was conducted on $\mathrm{d} 0, \mathrm{~d} 2$, and daily thereafter, beginning with $\mathrm{PGF}_{2 \alpha}$ treatment through 72 $\mathrm{h}$ after $\mathrm{PGF}_{2 \alpha}$, to monitor ovarian structures. Ovarian follicles were mapped and sized on d 0 and 2 to determine responses to the first $\mathrm{GnRH}$ injection. In subsequent scans, all follicles were mapped and sized to monitor the dominant ovarian follicle that developed after the first GnRH injection, and that later became the preovulatory follicle. Follicles were assumed to be spherical. Diameter of structures was determined by averaging their largest cross-sectional width and height measured by ultrasound electronic calipers. Volume of follicles and CL was calculated as follows:

$$
\begin{gathered}
\text { Radius }=(\mathrm{W} / 2+\mathrm{H} / 2) / 2 \text {, where } \mathrm{W}=\text { largest width } \\
\text { and } \mathrm{H}=\text { largest height of structure; } \\
\text { Volume }=4 / 3 \times \mathrm{R}^{3} \times \pi \text {, where } \mathrm{R}=\text { radius and } \pi=3.14159 .
\end{gathered}
$$

Blood samples were collected from a coccygeal vessel on $\mathrm{d} 0, \mathrm{~d} 2$, and then daily beginning with $\mathrm{PGF}_{2 \alpha}$ treatment through $72 \mathrm{~h}$ after $\mathrm{PGF}_{2 \alpha}, \mathrm{d} 14$, and $\mathrm{d} 21$. The samples were stored on ice, and serum concentrations of P4 were later quantified by RIA (Skaggs et al., 1986). Intra- and interassay coefficients of variation for the P4 RIA were 7.7 and $11.4 \%$, respectively, for a sample that averaged $3.2 \pm 0.1 \mathrm{ng} / \mathrm{mL}$. In blood samples collected on $\mathrm{d} 0, \mathrm{~d} 2$, and daily beginning with $\mathrm{PGF}_{2 \alpha}$ treatment through $48 \mathrm{~h}$ after $\mathrm{PGF}_{2 \alpha}$, serum concentrations of E2$17 \beta$ were quantified in a single RIA (Perry et al., 1991). To increase assay sensitivity, modifications included incubating dried serum extracts with E2-17 $\beta$ antiserum for $24 \mathrm{~h}$ at $20^{\circ} \mathrm{C}$ before adding ${ }^{125}$ I-labeled E2-17 $\beta$ and incubating assay tubes for an additional $6 \mathrm{~h}$ at $20^{\circ} \mathrm{C}$. After that 6 -h incubation, bound E2-17 $\beta$ was separated from free $\mathrm{E} 2-17 \beta$ by adding cold $\left(5^{\circ} \mathrm{C}\right)$ dextran-coated charcoal. The intraassay coefficient of variation was $7.8 \%$ for a sample that averaged $18.9 \pm 0.6 \mathrm{pg} / \mathrm{mL}$. Sensitivity of the assay was $<0.05 \mathrm{pg} / \mathrm{tube}$.

\section{Statistical Analyses}

All analyses were performed by using SAS software (SAS Inst. Inc., Cary, NC). All pretreatment variables were analyzed by ANOVA (GLM procedure) by applying a model that consisted of only lactation number $(1,2$, and $3+)$. Posttreatment continuous variables were analyzed similarly with a model that included treatment (7-, 8-, or 9-d interval between the first $\mathrm{GnRH}$ injection and the treatment $\mathrm{PGF}_{2 \alpha}$ injection), lactation number, and treatment by lactation number interaction. Binomial data (percentages and proportions) were analyzed by logistic regression (GENMOD procedure) using the same model.

Changes in follicular diameters, follicular volumes, and serum concentrations of $\mathrm{P} 4$ and $\mathrm{E} 2-17 \beta$, across days of the experiment or standardized to the day of $\mathrm{PGF}_{2 \alpha}$ treatment, were analyzed by using a mixed model procedure (MIXED procedure) to account for repeated measures. Because lactation number had no effects on treatment outcomes, the model consisted of treatment, cow within treatment (random), day, and treatment by day interaction. The covariance structure varied with model. The final model chosen for each variable produced the smallest Akaike's information criteria (AIC). Most covariance structures were heterogeneous autoregressive, but a few were heterogeneous compound symmetry. A priori contrasts were constructed to compare treatment on $\mathrm{d} 7$ (control) with each of the other 2 treatments.

\section{RESULTS}

\section{Pretreatment Responses}

Estrus was expressed by 22 of 36 cows after removal of the CIDR insert, as detected by electronic, pressuresensitive HeatWatch transmitters (CowChips LLC, Denver, CO). Interval to estrus after CIDR insert removal was $52.1 \pm 4.6 \mathrm{~h}$ (ranged from 24 to $114 \mathrm{~h}$ ). Average number of standing events was $3.8 \pm 0.7$, with a total duration of standing time of $9 \pm 2 \mathrm{~s}$. Duration of estrus was $6.3 \pm 1.1 \mathrm{~h}$. Of those cows that expressed estrus, days from estrus to injection of GnRH was d $6.4 \pm 0.2$ (range of d 3.7 to 7.4).

Ovarian responses and characteristics of cows before treatments were imposed are summarized in Table 1. Of 36 cows treated, 4 cows were found anestrous by using information from ovarian scans, lack of expressed estrus after CIDR insert removal, and serum concentrations of P4. Two of those 4 cows failed to ovulate in response to $\mathrm{GnRH}$. The CL failed to regress in response to $\mathrm{PGF}_{2 \alpha}$ treatment in 2 additional cows. Therefore, 4 cows (2 anestrous cows and 2 cows having no luteolysis) were eliminated from the study, leaving a total of 32 cows in the 3 treatments.

In the 32 cows studied, pretreatment responses summarized in Table 2 include numbers of original, induced, and total CL; total numbers of follicles $\geq 10 \mathrm{~mm}$ in diameter before $\mathrm{GnRH}$; and diameter and volume of the largest follicle and resulting diameter and volume of the CL that formed after ovulation (assessed $7 \mathrm{~d}$ after the first injection of $\mathrm{GnRH})$. In addition, in 29 of 32 (90.6\%) cows, at least 1 follicle ovulated in response to $\mathrm{GnRH}$. Of the 
Table 1. Ovarian responses of 36 cows assigned to treatment assessed at 7, 8, or $9 \mathrm{~d}$ after the first GnRH injection of a modified Ovsynch protocol

\begin{tabular}{lrrr}
\hline & \multicolumn{3}{c}{$\begin{array}{c}\text { Interval between first GnRH } \\
\text { injection and } \mathrm{PGF}_{2 \alpha}, \mathrm{d}\end{array}$} \\
\cline { 2 - 4 } Item & 7 & 8 & 9 \\
\hline Cows assigned, no. & 13 & 11 & 12 \\
Expressed estrus after CIDR insert removal, no. & 7 & 7 & 8 \\
Cows having original CL, no. & 11 & 9 & 11 \\
Anestrous cows, ${ }^{\text {no. }}$ & 1 & 2 & 1 \\
Anestrous cows that ovulated, no. & 1 & 7 & 11 \\
Cows having induced CL, no. & 11 & 4 & 1 \\
Cows having no induced CL, no. & 2 & 1 & 1 \\
Cows having no luteolysis, ${ }^{2}$ no. & 0 & 9 & 10 \\
Total cows studied per treatment, no. & 13 & 7
\end{tabular}

${ }^{1}$ Two anestrous cows that did not ovulate in response to the first GnRH injection were eliminated from all analyses ( 1 cow in the 8- and 1 cow in the 9-d treatments).

${ }^{2}$ Two cows not having luteolysis were eliminated from all analyses.

3 cows not ovulating in response to the first $\mathrm{GnRH}$ injection, 1 had 2 original CL and 2 had 1 original CL.

Distribution of CL is shown in Figure 2 based on the number of CL per cow assessed before and $7 \mathrm{~d}$ after GnRH. Two anestrous cows had no CL before GnRH, whereas 1 cow had 3 CL before GnRH was administered. One new CL was induced in 23 cows and 2 new CL in 4 cows, so the number of total CL ranged from $1 \mathrm{CL}$ in 4 cows, 2 CL in 17 cows, and 3 or more CL in 11 cows.

\section{Treatment Responses}

Changes in average diameter of the largest (putative dominant) follicle, monitored after the first GnRH injection, that subsequently ovulated are illustrated in Figure 3. Small differences were detected among treatments in the diameter of the largest follicle from $\mathrm{d} 2$ to 10 . Cows in the 9-d treatment had slightly smaller $(P<0.05)$ follicle diameters on $\mathrm{d} 2$ to 9 . Average diameter or average volume of the resulting preovulatory follicles assessed at $72 \mathrm{~h}$ after $\mathrm{PGF}_{2 \alpha}$, did not differ among treatments (Table 3). When diameters (Figure 4) and volumes (not shown) of the preovulatory follicles were standardized to the day when $\mathrm{PGF}_{2 \alpha}$ treatment was administered, no differences were detected among treatments. At least 1 follicle ovulated per cow (range of 1 to 2), and ovulation rates did not differ among treatments (Table 3).

Serum concentrations of E2-17 $\beta$ differed $(P \leq 0.05)$ among treatments when plotted by days since the first GnRH injection (Figure 5; upper panel). On d 8, and because of earlier treatment-induced luteolysis, cows in the 7 -d treatment ( $24 \mathrm{~h}$ after $\mathrm{PGF}_{2 \alpha}$ ) already had greater concentrations of E2-17 $\beta$ than did cows in the 8- and 9$\mathrm{d}$ treatments; this trend continued to $\mathrm{d} 9$. Once concentrations of $\mathrm{E} 2-17 \beta$ were expressed relative to days since $\mathrm{PGF}_{2 \alpha}$, treatment, differences were no longer evident (Figure 5; bottom panel).

A treatment by day interaction $(P<0.001)$ was detected for serum concentrations of $\mathrm{P} 4$ for $\mathrm{d} 0$ to 9 (Figure 6 ; upper panel). Concentrations of $\mathrm{P} 4$ were greater $(P<$ 0.05 ) on d 0 to 9 for cows in the 8- and 9-d treatments than for those in the 7-d treatment. When concentrations of $\mathrm{P} 4$ were reanalyzed as a percentage of concentrations on d 0 , similar patterns of $\mathrm{P} 4$ emerged and yielded a significant interaction that was likely caused by differences in designed timing of $\mathrm{PGF}_{2 \alpha}$-induced luteolysis. Further, patterns of luteal regression, as assessed by decreasing concentrations of $\mathrm{P} 4$ at 24 and $48 \mathrm{~h}$ after

Table 2. Pretreatment follicular and luteal characteristics, before and in response to, the first GnRH injection

\begin{tabular}{lcc}
\hline Item & Average & SD \\
\hline Original corpus luteum (CL) per cow, no. & $1.38(32)$ & 0.68 \\
New CL per cow, no. & $0.97(32)$ & 0.54 \\
Total CL per cow, no. & $2.25(32)$ & 0.76 \\
Cows that ovulated at least 1 follicle, \% & $90.6(32)$ & 0.94 \\
Total follicles $\geq 10 \mathrm{~mm}$ before first GnRH injection, no. & $1.88(32)$ & 2.4 \\
Diameter of largest ovulating follicle, mm & $12.6(28)^{1}$ & 755 \\
Volume of largest ovulating follicle, $\mathrm{mm}^{3}$ & $1,163(28)^{1}$ & 3.9 \\
Diameter of resulting CL, mm & $20.7(29)$ & 2,340 \\
Volume of resulting CL, $\mathrm{mm}^{3}$ & $4,687(29)$ & \\
\hline
\end{tabular}

${ }^{1}$ In one cow, the follicle was missed on $\mathrm{d} 0$, but a new CL was identified at $48 \mathrm{~h}$ and later. 


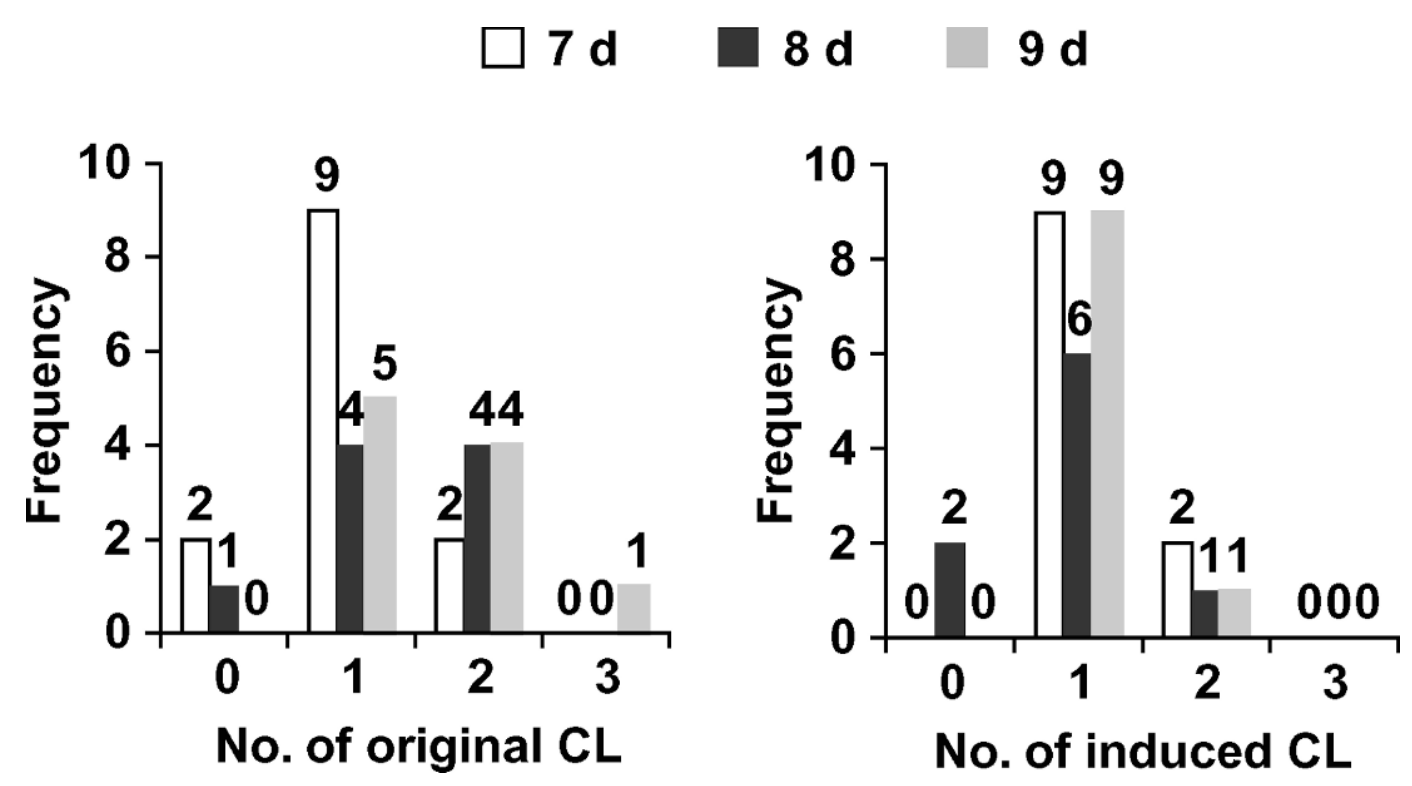

Figure 2. Distribution of original corpus luteum (CL) and those induced by the first GnRH injection, grouped by subsequent treatments of $\mathrm{PGF}_{2 \alpha}$ administered 7, 8, or $9 \mathrm{~d}$ after $\mathrm{GnRH}$.

$\mathrm{PGF}_{2 \alpha}$, were not different when expressed relative to day of $\mathrm{PGF}_{2 \alpha}$ treatment injection (Figure 6; bottom panel). All 32 cows subsequently ovulated and formed new CL (Table 3) after treatment as is further evidenced by increased concentrations of $\mathrm{P} 4$ in serum at 14 and 21 $\mathrm{d}$ after the first GnRH injection (Figure 6; top panel).

Four cows in the 7-d treatment were inseminated 24 $\mathrm{h}$ late (i.e., not according to protocol). Of the remaining cows, 5 of 9 cows (55.6\%) conceived in the 7-d treatment, and 5 of 9 cows (55.6\%) conceived in 8-d treatment, compared with only 1 of 10 cows (10\%) in the 9 -d treatment. Conception rates of individual 7- and 8-d treatments

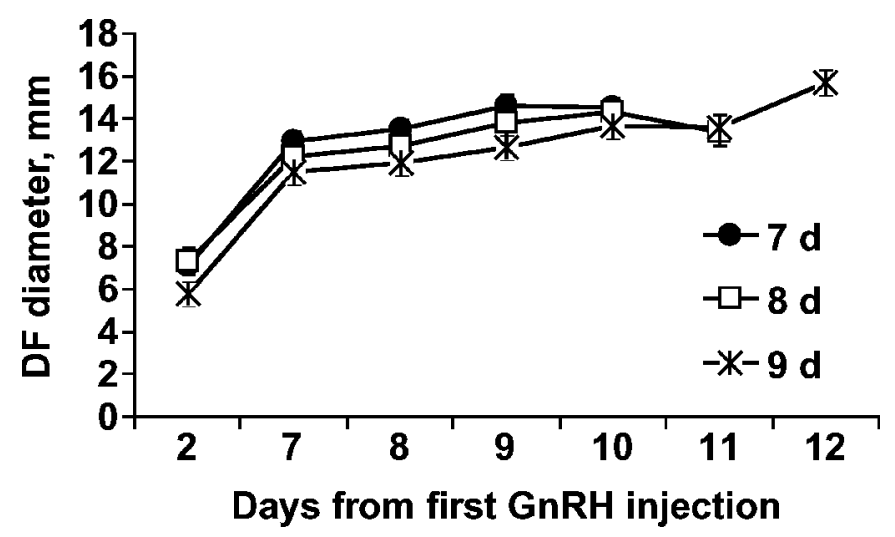

Figure 3. Changes in average diameter of the dominant follicle (DF) that eventually ovulated after each of 3 treatments in which $\mathrm{PGF}_{2 \alpha}$ was administered either $7 \mathrm{~d}(\mathrm{n}=13), 8 \mathrm{~d}(\mathrm{n}=9)$, or $9 \mathrm{~d}(\mathrm{n}=$ 10) after the first GnRH injection (d 0). tended $(P=0.07)$ to differ from that of the 9-d treatment. Two of the 4 cows $(50 \%)$ that failed to ovulate after the first GnRH injection conceived, whereas 9 of 24 cows (37.5\%) conceived that ovulated at least 1 follicle after the first $\mathrm{GnRH}$ injection.

\section{DISCUSSION}

Our model allowed us to test the hypothesis that delaying luteolysis up to $48 \mathrm{~h}$ after a normal 7-d interval between $\mathrm{GnRH}$ and $\mathrm{PGF}_{2 \alpha}$ in an Ovsynch protocol would increase follicle size and $\mathrm{E} 2-17 \beta$ secretion. The uniform group of cows tested included 22 cows that were known to be between $d 3.7$ and 7.4 of the estrous cycle, and 29 of 32 cows had at least 1 follicle ovulate in response to the first GnRH injection. The large incidence (90.6\%) of ovulation in response to the first $\mathrm{GnRH}$ injection is consistent with earlier reports for cows at similar stages of the estrous cycle (Vasconcelos et al., 1999).

We hypothesized that greater concentrations of serum E2-17 $\beta$ in lactating cows might occur when using the Ovsynch protocol if $\mathrm{PGF}_{2 \alpha}$-induced luteolysis was delayed after the first GnRH injection. Our treatments, however, failed to produce larger follicles and did not result in greater concentrations of serum E2-17 $\beta$. Neither diameter or volume of the preovulatory follicle nor concentrations of E2-17 $\beta$ were increased by lengthening the period of dominance for the newly recruited dominant follicle.

In heifers, restricting duration of dominance of the preovulatory follicle to $\leq 4 \mathrm{~d}$ at the onset of estrus led to 
Table 3. Largest diameter and volume of preovulatory follicles that ovulated after treatment in response to the second GnRH injection and resulting ovulation rate

\begin{tabular}{|c|c|c|c|}
\hline \multirow[b]{2}{*}{ Measure $^{1}$} & \multicolumn{3}{|c|}{$\begin{array}{l}\text { Interval between first } \mathrm{GnRH} \\
\text { injection and } \mathrm{PGF}_{2 \alpha}, \mathrm{d}\end{array}$} \\
\hline & 7 & 8 & 9 \\
\hline Diameter of largest follicle, $\mathrm{mm}$ & $14.3 \pm 0.6$ & $14.1 \pm 0.8$ & $15.3 \pm 0.9$ \\
\hline Volume of largest follicle, $\mathrm{mm}^{3}$ & $1,526 \pm 62$ & $1,479 \pm 97$ & $1,490 \pm 69$ \\
\hline Ovulation rate & $1.2 \pm 0.1$ & $1.1 \pm 0.1$ & $1.3 \pm 0.2$ \\
\hline
\end{tabular}

${ }^{1}$ Assessed $72 \mathrm{~h}$ after $\mathrm{PGF}_{2 \alpha}$ in each treatment.

more precise estrus and a higher conception rate (Austin et al., 1999). This duration of dominance would be most consistent with cows in our 7- or 8-d treatments. In a recent review (Tenhagen, 2005), it was concluded that intervals of $7 \mathrm{~d}$ between $\mathrm{GnRH}$ and $\mathrm{PGF}_{2 \alpha}$ were most effective relative to fertility when the second $\mathrm{GnRH}$ followed $\mathrm{PGF}_{2 \alpha}$ by $48 \mathrm{~h}$ and insemination occurred 16 to $20 \mathrm{~h}$ later.

Clear differences seem to exist between lactating and nonlactating cows with regard to size of ovarian structures and their steroid-secreting capacity, indicating that lactation per se, age, or both, creates these differences. Lactating cows have a much greater incidence of ovulation failure after luteolysis, more multiple ovulations, lower serum E2-17 $\beta$ concentrations, and larger follicles and CL than do nulliparous heifers (Sartori et al., 2004). Moreover, expression of estrus (Dransfield et al., 1998) and estrus-detection rates (Stevenson, 2001) are reduced in lactating dairy cows probably as a result of less estrogen exposure during the periestrual period. Among lactating cows, cows producing more milk have shorter durations of estrus, fewer numbers of standing events, and less total standing time than do lower-producing cows (Lopez et al., 2004). It seems clear that

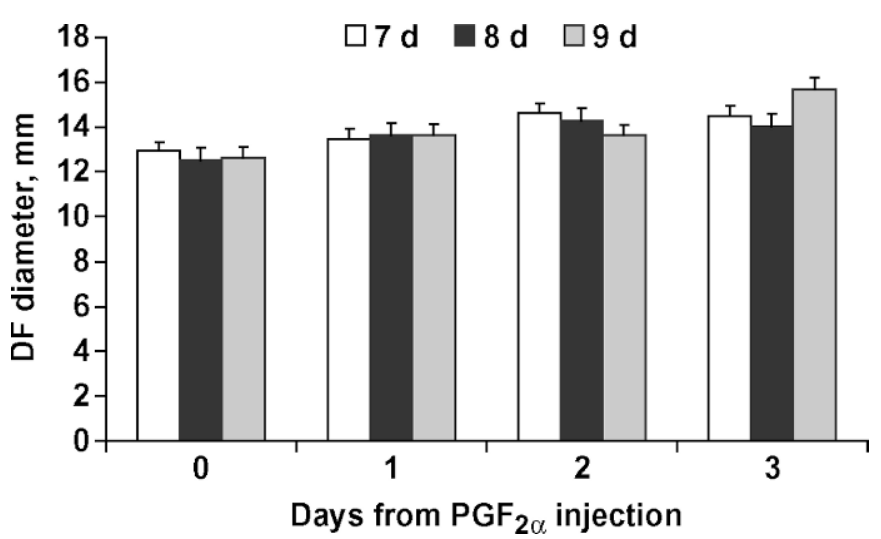

Figure 4. Average diameter of the preovulatory (dominant) follicle (DF) in cows treated with $\mathrm{PGF}_{2 \alpha}$ either $7(\mathrm{n}=13), 8(\mathrm{n}=9)$, or $9(\mathrm{n}=$ 10) $d$ after the first injection of GnRH. Diameters were standardized to the day of $\mathrm{PGF}_{2 \alpha}$ treatment. lactating cows require a larger follicle and greater E2$17 \beta$ production to achieve adequate circulating concentrations of E2-17 $\beta$ necessary to produce an LH surge and ovulation compared with nonlactating cows (Sartori et al., 2002). In our study, concentrations of E2-17 $\beta$ were not increased by prolonged growth and dominance of the newly recruited follicles after the first GnRH injection.

Discrepancies between sizes of ovarian structures and serum steroid concentrations may be due to greater rates of steroid metabolism in lactating dairy cows than in
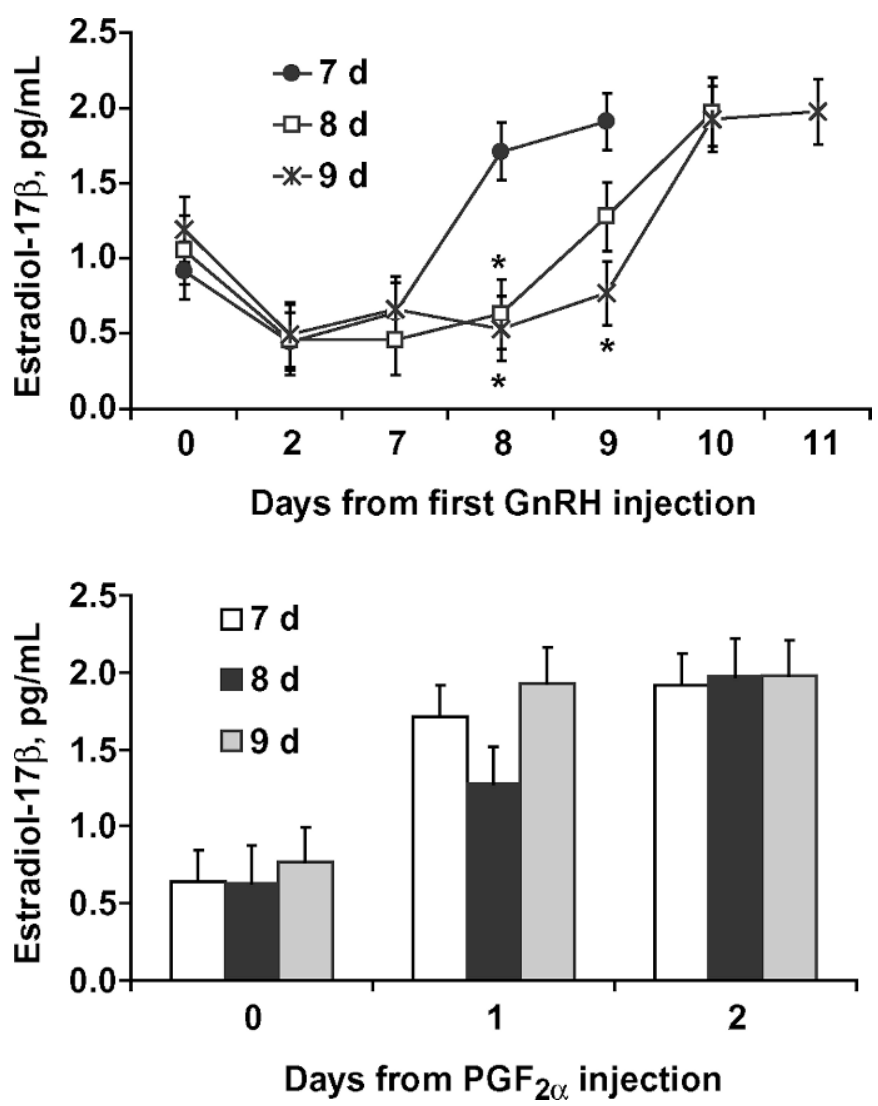

Figure 5. Serum concentrations of estradiol-17 $\beta$ (E2-17 $\beta)$ in cows after the first $\mathrm{GnRH}$ injection, and in response to $\mathrm{PGF}_{2 \alpha}$ treatment administered $7(\mathrm{n}=13), 8(\mathrm{n}=9)$, or $9(\mathrm{n}=10) \mathrm{d}$ after the first injection of GnRH (top panel). Serum E2-17 $\beta$ is standardized to the day of $\mathrm{PGF}_{2 \alpha}$ injection (bottom panel). 

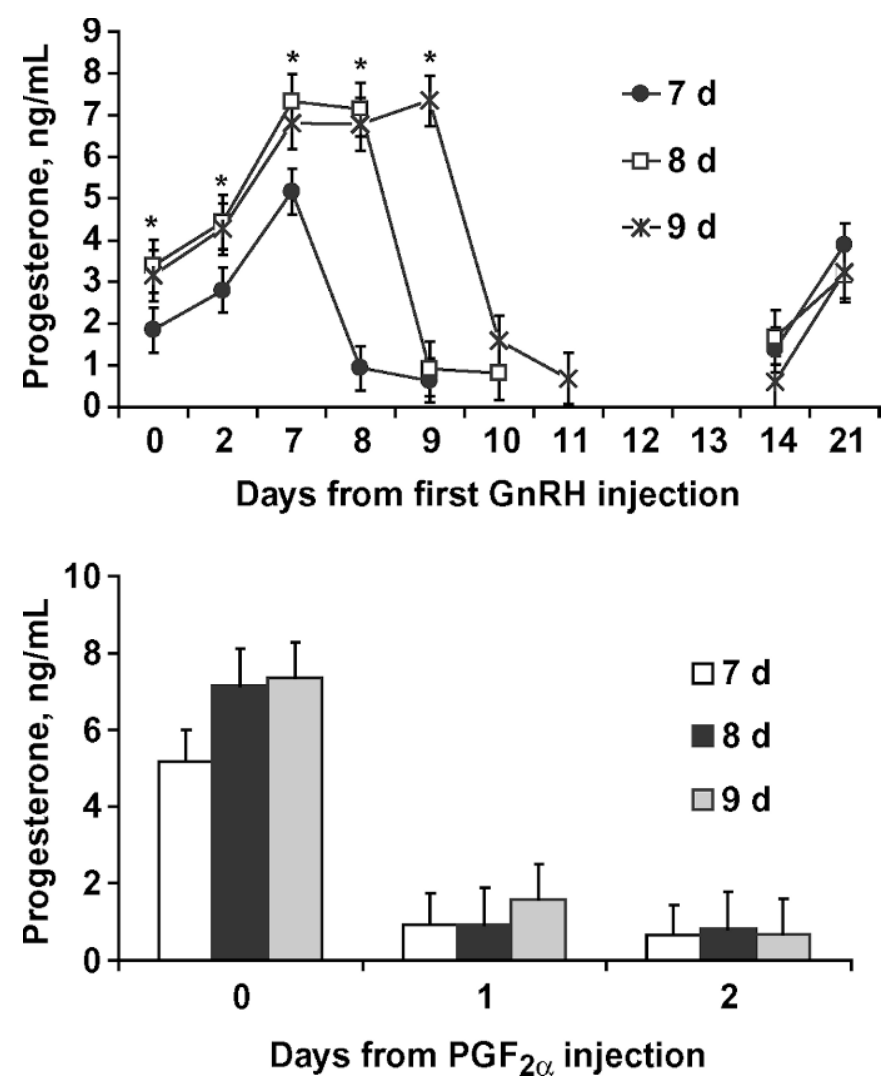

Figure 6. Serum concentrations of progesterone (P4) in cows from the first $\mathrm{GnRH}$ injection, and in response to $\mathrm{PGF}_{2 \alpha}$ treatment administered $7(n=13), 8(n=9)$, or $9(n=10) d$ after the first injection of $\mathrm{GnRH}$ (top panel). Serum P4 is standardized to the day of $\mathrm{PGF}_{2 \alpha}$ injection (bottom panel); *different $(P \leq 0.05)$ from d 7 (control).

heifers (Sangsritavong et al., 2002). Further, it is clear that these differences cannot be explained by differences in patterns of follicular waves (Sartori et al., 2004). Based on those studies (Sangsritavong et al., 2002; Sartori et al., 2004), it seems that the lactating cow metabolizes E2-17 $\beta$ more quickly, resulting in inadequate peripheral concentrations of E2-17 $\beta$ to support events associated with normal fertility. It is not known, however, whether $\mathrm{E} 2-17 \beta$ biosynthesis by antral follicles may be inferior because of lactation. Further, high-producing cows had lower E2-17 $\beta$ concentrations than low-producing cows, despite having larger preovulatory follicles (Lopez et al., 2004). Interestingly, E2-17 $\beta$ concentrations were not correlated with diameter of the preovulatory follicle, but milk production was correlated with both $\mathrm{E} 2-17 \beta$ concentrations and diameter of the preovulatory follicle. It is clear that prolonging the life span of the dominant follicle (preovulatory follicle) in our study failed to increase either follicle size or peripheral concentrations of serum E2-17 $\beta$.

Other attempts to increase concentrations of estrogen during the periestrual period have been made. Studies in which 0.5 to $1 \mathrm{mg}$ of estradiol cypionate (ECP) was injected in combination with ovulation synchronization indicated that injecting ECP $24 \mathrm{~h}$ after $\mathrm{PGF}_{2 \alpha}$ may not increase conception rates in lactating dairy cows (Pancarci et al., 2002; Stevenson and Tiffany, 2004; Stevenson et al., 2004). Further, when $0.25 \mathrm{mg}$ of ECP was administered at $48 \mathrm{~h}$ after $\mathrm{PGF}_{2 \alpha}$, concomitant with the second GnRH injection of Ovsynch, concentrations of serum E2$17 \beta$ were greater at 6 and $12 \mathrm{~h}$ after injection than in controls, which only received $\mathrm{GnRH}$, but conception rates did not differ between treatments (Sellars et al., 2006).

Lactating dairy cows were administered $1 \mathrm{mg}$ of E2$17 \beta$ (shorter acting and shorter half-life estrogen than ECP; Vynckier et al., 1990) $8 \mathrm{~h}$ before the second GnRH injection and compared with cows treated with an Ovsynch-like protocol, in which the second GnRH injection was delayed to $54 \mathrm{~h}$ after $\mathrm{PGF}_{2 \alpha}$, and TAI occurred 16 $\mathrm{h}$ later (Souza et al., 2005). Treatment with E2-17 $\beta$ tended to improve conception rate in cows having lower BCS ( $\leq 2.5)$, cows in their first lactation, and cows ovulating medium-size (15 to $19 \mathrm{~mm}$ ) follicles compared with cows treated with Ovsynch alone.

Injection of estrogen or increased exposure of cows to endogenous estrogen increased the incidence of estrus in previous studies (Pancarci et al., 2002; Stevenson et al., 2004), which may benefit fertility in some instances (Souza et al., 2005). Furthermore, other positive benefits of estrogen include induction of normal estrual characteristics, such as mucus secretion, uterine tone, and resulting sexual behavior. These traits are positive indicators of estrus for inseminators because they validate the likelihood of the cow being in estrus (Pancarci et al., 2002).

Although too few cows were inseminated to test differences in conception rates, only 1 of 10 cows in the 9-d treatment conceived when inseminated at $48 \mathrm{~h}$ after $\mathrm{PGF}_{2 \alpha}$ compared with 5 of 9 cows conceiving in each of the 7- or 8-d treatments. In cows whose estrous cycles are presynchronized before Ovsynch, reproductive outcomes may not be reduced when $\mathrm{PGF}_{2 \alpha}$ injection is delayed by $24 \mathrm{~h}$ from the standard 7-d period between GnRH and $\mathrm{PGF}_{2 \alpha}$ injections, but $48 \mathrm{~h}$ may be too long to prevent a potentially reduced conception rate.

In conclusion, prolonging the life span of a newly recruited dominant follicle in the presence of a functional CL by 24 to $48 \mathrm{~h}$, from the standard 7-d interval between the first GnRH injection of the Ovsynch protocol and the injection of $\mathrm{PGF}_{2 \alpha}$, failed to increase serum concentrations of $\mathrm{E} 2-17 \beta$ or the diameter of that dominant follicle. Further study is warranted to verify whether delaying $\mathrm{PGF}_{2 \alpha}$ injections by $24 \mathrm{~h}$ has no effects on fertility and whether $\mathrm{PGF}_{2 \alpha}$ injections may be given late (d 8), when not given at $\mathrm{d} 7$ as planned. 


\section{ACKNOWLEDGMENTS}

The authors thank support staff at the Kansas State University Dairy Teaching and Research Center for their able assistance in conducting this study, particularly M. Scheffel and W. Jackson. We thank Irene Vanderwerff for assistance with laboratory procedures.

\section{REFERENCES}

Austin, E. J., M. Mihm, M. P. Ryan, D. H. Williams, and J. F. Roche. 1999. Effect of duration of dominance of the ovulatory follicle on onset of estrus and fertility in heifers. J. Anim. Sci. 77:2219-2226.

Dransfield, M. B. G., R. L. Nebel, R. E. Pearson, and L. D. Warnick. 1998. Timing of insemination for dairy cows identified in estrus by a radiotelemetric estrus detection system. J. Dairy Sci. 81:1874-1882.

Lopez, H., L. D. Satter, and M. C. Wiltbank. 2004. Relationship between level of milk production and estrous behavior of lactating dairy cows. Anim. Reprod. Sci. 89:209-223.

Lucy, M. C. 2001. Reproductive loss in high-producing dairy cattle: Where will it end? J. Dairy Sci. 84:1277-1293.

National Animal Health Monitoring System. 1996. Part 1. Reference of 1996 Dairy Management Practices. Page 14. http://www.aphis. usda.gov/vs/ceah/ncahs/nahms/dairy/dairy96/DR96Pt1.pdf

National Research Council. 2001. Nutrient Requirements of Dairy Cattle. 7th rev. ed. Natl. Acad. Sci., Washington, DC.

Pancarci, S. M., E. R. Jordan, C. A. Risco, M. J. Schouten, F. L. Lopes, F. Moreira, and W. W. Thatcher. 2002. Use of estradiol cypionate in a presynchronized timed artificial insemination program for lactating dairy cattle. J. Dairy Sci. 85:122-131.

Perry, R. C., L. R. Corah, G. H. Kiracofe, J. S. Stevenson, and W. E. Beal. 1991. Endocrine changes and ultrasonography of ovaries in suckled beef cows during resumption of postpartum estrous cycles. J. Anim. Sci. 69:2548-2555.

Pursley, J. R., M. W. Kosorok, and M. C. Wiltbank. 1997. Reproductive management of lactating dairy cows using synchronization of ovulation. J. Dairy Sci. 80:301-306.

Pursley, J. R., M. E. Mee, and M. C. Wiltbank. 1995. Synchronization of ovulation in dairy cows using $\mathrm{PGF}_{2 \alpha}$ and $\mathrm{GnRH}$. Theriogenology 44:915-923.

Sangsritavong, S., D. K. Combs, R. Sartori, L. E. Armentano, and M. C. Wiltbank. 2002. High feed intake increases liver blood flow and metabolism of P4 and estradiol-17 $\beta$ in dairy cattle. J. Dairy Sci. 85:2831-2842.

Sartori, R., J. M. Haughian, R. D. Shaver, G. J. M. Rosa, and M. C. Wiltbank. 2004. Comparison of ovarian function and circulating steroids in estrous cycles of Holstein heifers and lactating cows. J. Dairy Sci. 87:905-920.

Sartori, R., G. J. M. Rosa, and M. C. Wiltbank. 2002. Ovarian structures and circulating steroids in heifers and lactating cows in summer and lactating and dry cows in winter. J. Dairy Sci. 85:2813-2822.

Sellars, C. B., J. C. Dalton, R. Manzo, J. Day, and A. Ahmadzadeh. 2006. Time and incidence of ovulation and conception rates after incorporating estradiol cypionate into a timed artificial insemination protocol. J. Dairy Sci. 89:620-626.
Skaggs, C. L., B. V. Able, and J. S. Stevenson. 1986. Pulsatile or continuous infusion of luteinizing hormone-releasing hormone and hormonal concentrations in prepubertal beef heifers. J. Anim. Sci. 62:1034-1048.

Souza, A. H., A. Gumen, E. P. B. Silva, A. P. Cunha, J. N. Guenther, C. M. Peto, D. Z. Caraviello, and M. C. Wiltbank. 2005. Effect of estradiol-17 $\beta$ supplementation before the last GnRH of the Ovsynch protocol in high producing dairy cows. J. Dairy Sci. 88(Suppl. 1):170. (Abstr.)

Stevenson, J. S. 2001. A review of oestrous behaviour and detection in dairy cows. Pages 43-62 in Fertility in the High-Producing Dairy Cow. Vol. 1. Br. Soc. Anim. Sci. Occ. Pub. No. 26. Br. Soc. Anim. Sci., Edinburgh, UK.

Stevenson, J. S., Y. Kobayashi, and K. E. Thompson. 1999. Reproductive performance of dairy cows in various programmed breeding systems including Ovsynch and combinations of gonadotropin-releasing hormone and prostaglandin $\mathrm{F}_{2 \alpha}$. J. Dairy Sci. 82:506-515.

Stevenson, J. S., and S. M. Tiffany. 2004. Resynchronizing estrus and ovulation after not-pregnant diagnosis and various ovarian states including cysts. J. Dairy Sci. 87:3658-3664.

Stevenson, J. S., S. M. Tiffany, and M. C. Lucy. 2004. Use of estradiol cypionate as a substitute for GnRH in protocols for synchronizing ovulation in dairy cattle. J. Dairy Sci. 87:3298-3305.

Tenhagen, B. A. 2005. Factors influencing conception rate after synchronization of ovulation and timed artificial insemination-A review. Dtsch. Tieraerztl. Wochenschr. 112:136-141.

Thatcher, W. W., K. L. Macmillan, P. J. Hansen, and M. Drost. 1989. Concepts for regulation of corpus luteum function by the conceptus and ovarian follicles to improve fertility. Theriogenology 31:149164.

Twagiramungu, H., L. A. Guilbault, and J. J. DuFour. 1995. Synchronization of ovarian follicular waves with a gonadotropin-releasing hormone agonist to increase the precision of estrus in cattle: A review. J. Anim. Sci. 73:3141-3151.

Twagiramungu, H., L. A. Guilbault, J. Proulx, and J. J. Dufour. 1992a. Synchronization of estrus and fertility in beef cattle with two injections of buserelin and prostaglandin. Theriogenology 38:11311144 .

Twagiramungu, H., L. A. Guilbault, J. G. Proulx, and J. J. Dufour. 1994a. Influence of corpus luteum and induced ovulation on ovarian follicular dynamics in postpartum cyclic cows treated with buserelin and cloprostenol. J. Anim. Sci. 72:1796-1805.

Twagiramungu, H., L. A. Guilbault, J. Proulx, R. Ramkumar, and J. J. Dufour. 1994b. Histological populations and atresia of ovarian follicles in postpartum cattle treated with an agonist of gonadotropin-releasing hormone. J. Anim. Sci. 72:192-200.

Twagiramungu, H., L. A. Guilbault, J. Proulx, P. Villeneuve, and J. J. Dufour. 1992b. Influence of an agonist of gonadotropin releasing hormone (Buserelin) on estrus synchronization and fertility in beef cows. J. Anim. Sci. 70:1904-1910.

Vasconcelos, J. L. M., R. W. Silcox, G. J. Rosa, J. R. Pursley, and M. C. Wiltbank. 1999. Synchronization rate, size of the ovulatory follicle, and pregnancy rate after synchronization of ovulation beginning on different days of the estrous cycle in lactating dairy cows. Theriogenology 52:1067-1078.

Vynckier, L., M. Debackere, A. De Kruif, and M. Coryn. 1990. Plasma estradiol- $17 \beta$ concentrations in the cow during induced estrus and after injection of estradiol-17 $\beta$ benzoate and estradiol-17 $\beta$ cypionate: A preliminary study. J. Vet. Pharmacol. Therap. 13:36-42. 